\title{
Effect of a Submerged Zone and Carbon Source on Nutrient and Metal Removal for Stormwater by Bioretention Cells
}

\author{
Mo Wang ${ }^{1,2,3, * \mathbb{D}}$, Dongqing Zhang ${ }^{4}$, Yong $\mathrm{Li}^{2}$, Qinghe Hou ${ }^{1}$, Yuying $\mathrm{Yu}^{2}$, Jinda $\mathrm{Qi}^{5}$, \\ Weicong Fu ${ }^{6}$, Jianwen Dong ${ }^{6}$ and Yuning Cheng ${ }^{1, *}$ \\ 1 School of Architecture, Southeast University, Nanjing 210096, China; HomeHouqinghe@outlook.com \\ 2 College of Architecture and Urban Planning, Guangzhou University, Guangzhou 510006, China; \\ saupgzddld@gzhu.edu.cn (Y.L.); tcyyuying@outlook.com (Y.Y.) \\ 3 Biophilic Lab, Z + T Studio, Shanghai 200052, China \\ 4 Nanyang Environment \& Water Research Institute, Nanyang Technological University, \\ Singapore 637141, Singapore; Katherinedongqingzhang@gmail.com \\ 5 Faculty of Built Environment, University of New South Wales, Sydney, NSW 2052, Australia; \\ Jinda.qi@unsw.edu.au \\ 6 College of Landscape Architecture, Fujian Agriculture and Forestry University, Fuzhou 350002, China; \\ weicongfufj@163.com (W.F.); fjdjw@126.com(J.D.) \\ * Correspondence: landwangmo@outlook.com (M.W.); landchengyuning@gmail.com (Y.C.)
}

Received: 13 August 2018; Accepted: 7 November 2018; Published: 12 November 2018

\begin{abstract}
A bioretention system is a low-impact and sustainable treatment facility for treating urban stormwater runoff. To meet or maintain a consistently satisfactory performance, especially in terms of increasing nitrogen removal efficiency, the introduction of a submerged (anoxic) zone (SZ) combined with a module-based carbon source $(\mathrm{C})$ has been recommended. This study investigated the removal of nitrogen $(\mathrm{N})$, phosphorus $(\mathrm{P})$ and heavy metals with a retrofitted bioretention system. A significant $(p<0.05)$ removal enhancement of $\mathrm{N}$ as well as total phosphorus (TP) was observed, in the mesocosms with additions of exogenous carbon as opposed to those without such condition. However, even in the mesocosm with SZ alone (without exogenous C), TP removal showed significant enhancement. With regard to the effects of SZ depth on nutrient removal, the results showed that the removal of both $\mathrm{N}$ and $\mathrm{P}$ in module with a shallow SZ $(200 \mathrm{~mm})$ showed significant enhancement compared to that in module with a deep SZ (300 mm). Removal efficiencies greater than $93 \%$ were observed for all three heavy metals tested $(\mathrm{Cu}, \mathrm{Pb}$, and $\mathrm{Zn})$ in all mesocosms, even in the bioretention module without an SZ or plants, and it indicated that adsorption by the filtration media itself is probably the most important removal mechanism. Only $\mathrm{Cu}$ (but not $\mathrm{Pb}$ or $\mathrm{Zn}$ ) showed significantly enhanced removal in module with an SZ as compared to those without an SZ. Carbon source played a minor role in metal removal as no significant $(p>0.05)$ improvement was observed in module with $C$ as compared to that without $C$. Based on these results, the incorporation of $S Z$ with $C$ in stormwater biofilters is recommended.
\end{abstract}

Keywords: bioretention; nutrient; heavy metals; submerged zone; carbon source; stormwater

\section{Introduction}

Land use change caused by urbanization can cause detrimental impacts on natural waters as a consequence of infiltration decreasing and runoff volumes increasing dramatically by high-density and impervious surfaces [1,2]. Increased pollutant loads accumulated in surface runoff from impervious catchments without rational management discharged to the received water-bodies can make the quality 
of water irreversibly degraded [3,4]. Bioretention cells (BCs) integrated runoff retention areas, is a critical component of Low Impact Development (LID) practices receiving high attention as "green storm infrastructure" to manage storm runoff in a decentralized and source management approach $[5,6]$. BCs have gained popularity because of its design flexibility in terms of size and location, appealing landscape aesthetics, and hydrological performance for reduction of pollutants $[7,8]$. Previous studies have demonstrated that BCs implemented in relatively small catchments effectively improve both water quantity and quality in response to frequent storm events [9-11].

In the vegetated filter media, pollutants from storm runoff can be removed through a variety of mechanisms, including physical, chemical and biological processes [12-14], and its quality is further enhanced by plant uptake and biological activities in the rhizosphere $[15,16]$. In recent years, research has shown that BCs can effectively improve water quantity and remove suspended solids $[17,18]$, nutrients [19-21], and heavy metals [22,23]. However, it is difficult to meet or maintain a consistently satisfactory performance for reducing nitrogen due to a lack of effective denitrification [24,25].

Since it is difficult to achieve consistent high nitrogen removal in standard stormwater bioretention systems, a submerged (anoxic) zone (SZ) combined with a module of BCs added carbon source (C) (e.g., wood chips, shredded newspaper, sawdust etc.) has been used to improve the capacity for nitrogen removal by enhancing microbial denitrification [26-28]. Zinger et al. [29] investigated the nitrogen transformation in biofilters through the design optimization by adding SZ and C, and reported that nitrate removal of up to $99 \%$ was achieved. Similarly, Kim et al. [27] evaluated different electron-donor substrate (e.g., alfalfa, leaf mulch compost, newspaper, sawdust, wood chips and wheat straw) for denitrification, and demonstrated that newspaper-supported biological denitrification was the most efficient method under conditions of intermittent loading, and the pilot-scale modified bioretention system showed the mass removal for nitrate and nitrite up to $80 \%$. Zinger et al. [30] investigated the impact of drying/wetting cycling on biofilter performance, and revealed that the SZ was able to enhance biofilter nitration removal recovery and make it less dependent on drying/wetting.

However, controversial findings regarding to the role of a retrofitted SZ in the BCs were also observed in the previous studies [31]. Dietz and Clausen [32] reported that in their field experiment that there was no sufficient evidence of improvement on a reduction of nitrate when integrated with an SZ in BCs. Similarly, the results from field experiments of both BCs conducted at a campus of Maryland University, one of which was designed to consist of an anoxic zone, showed no obvious difference in removal provided by both modules [33]. Zinger et al. [28] revealed that TP removal was less efficient after retrofitting the $\mathrm{SZ}$ due to the presence of organic matter in the filter media with the SZ and the removal of metals was not affected in practical term, although $\mathrm{NO}_{\mathrm{x}}$ removal was significantly increased which enhanced overall $\mathrm{N}$ removal. Furthermore, the impact of SZ with carbon addition on metal removal has not been fully studied. It is of particular interest to ascertain whether the introduction of SZ and C will diminish the high metal removal achieved in standard bioretention design. Hence, it is still not clear whether the addition of SZ and C will significantly influence metal removal, since the trapping of the metals in the top layer of the soil plays a significant role in metal removal [34]. In addition, to date, little information on the impact of the depth of SZ on contaminant removal in BCs is available. Also, there is relatively limited data available on water quality improvement (e.g., as a function of hydraulic residence time (HRT) and detailed pollutant fate in retrofited BCs with the saturated zone) $[35,36]$.

Actually, BCs have been adopted by many urban catchments worldwide to reduce storm flows and improve runoff quality $[37,38]$. In recent years, integrating the LID practices with the urban catchment for the sustainability of urban hydrology under the Sponge City Programme has been strongly implemented in China [39]. Therefore, assessing the performance of LID practices including $\mathrm{BCs}$ is necessary for helping policymakers to determine the optimal plan for stormwater management, especially for the areas in China with rapid urbanization. In the present study, with great flexibility, the new modules designed can be implemented to fit easily into any site (e.g., car park, roadside planting verge, parks, small gardens or alongside a canal, etc.) as mesocosms (module systems). 
In the event of drainage layer clogging, the new modules can be lifted out for necessary maintenance. In addition, the modular system enables vegetation to be planted before installation on site and therefore speeds up the establishment process and reduces the chances of soil erosion that could occur in the initial planting phase. Although research on the bioretention system with a retrofitted SZ and carbon source has been carried out in Australia [40,41] and USA [42,43], to date, few studies has been reported regarding the performance of modified BCs for matching the interests of Sponge City construction in China, and it is essential that further advancement of knowledge on the performance of BCs for improving runoff quality should be carried out.

This paper presents the results of a mesocosm scale study on the removal of nutrients (nitrogen and phosphorus) and heavy metals (copper, zinc, and lead) using BCs for three different designs storms. The main objectives of this study were to (1) evaluate the effects of introduction of SZ combined with C on the pollutant removal; (2) assess the influences of different SZ depths on the reduction of contaminants; and (3) investigate the relationship between HRT and contaminant removal.

\section{Materials and Methods}

Four mesocosms including (a) module without plants; (b) module with plants, as well as an SZ (depth of $300 \mathrm{~mm}$ ) and C; (c) module with plants, as well as an SZ (depth of $200 \mathrm{~mm}$ ) and C; and (d) module with plants as well as an SZ (depth of $200 \mathrm{~mm}$ ), but without C, were set up at the campus of experimental plants, Shanghai, China. Figure 1 shows the layout of four bioretention systems. The dimensions of mesocosms were $1.20 \mathrm{~m} \times 1.20 \mathrm{~m} \times 1.20 \mathrm{~m}$ (length $\times$ width $\times$ depth). The mesocosms were housed under a transparent roof with open mesh on the sides, to ensure that only inflow water (rather than rainfall) was received during wet weather.

(a)

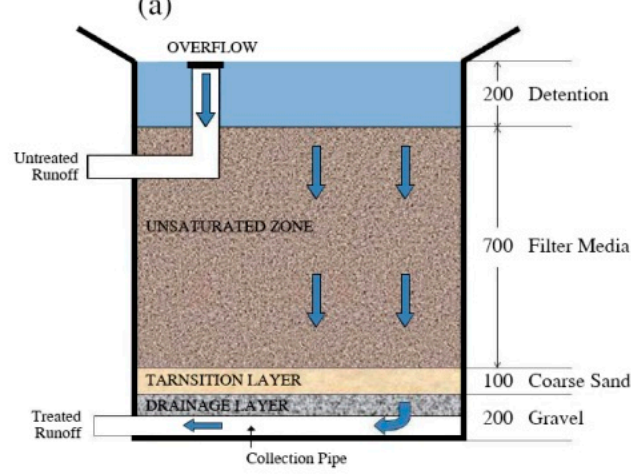

(c)

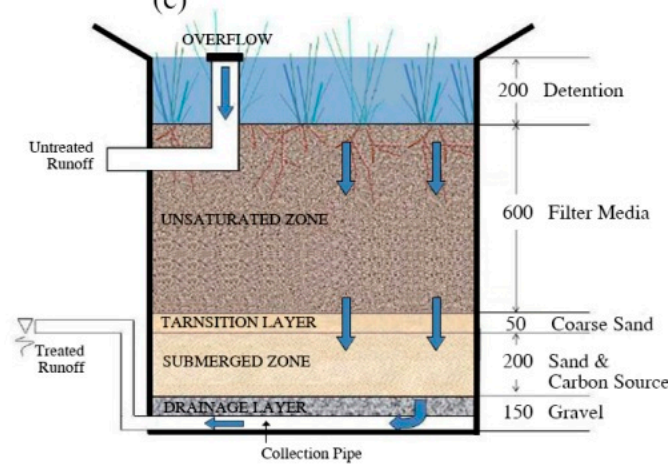

(b)

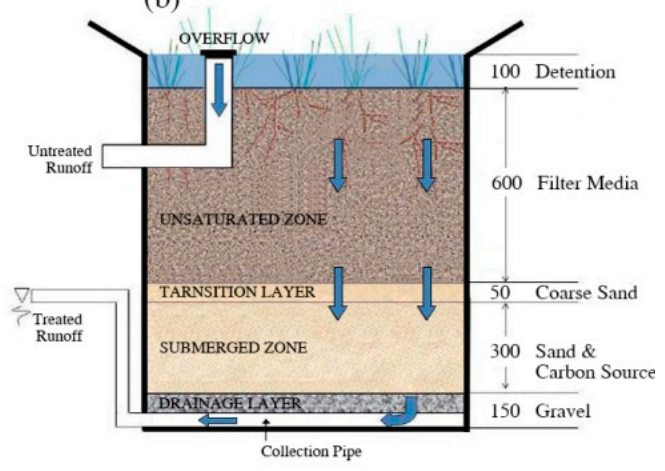

(d)

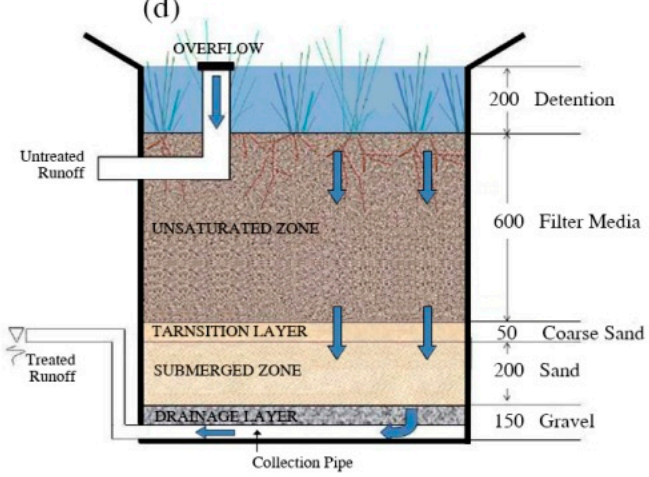

Figure 1. Layout of four bioretention mesocosms (unit: $\mathrm{mm}$ ). (a) module without plants or SZ; (b) module with plants, and a SZ (depth of $300 \mathrm{~mm}$ ) with C; (c) module with plants, and a SZ (depth of $200 \mathrm{~mm}$ ) with C; and (d) module with plants and a SZ (depth of $200 \mathrm{~mm}$ ). These figures are referenced to FAWB (Facility for Advancing Water Biofiltration) Adoption Guidelines for Stormwater Biofiltration Systems [44]. 
A prototype test run and seven column test runs were carried out to measure the permeability coefficient of modular retention media. The permeability of different soil depths was tested and the mean saturated hydraulic conductivity was $100 \mathrm{~mm} / \mathrm{h}$. The mesocosm in our study consisted of three layers. A description of the size, dimension, and property of the media in the mesocosm is as follows:

(a) Filter layer (600-700 mm, top to down): (i) sandy loam (50\%) (compost/washed sand ratio $=0.2: 1)[31,32]$; and (ii) medium to coarse sand $\left(1-2 \mathrm{~mm}\right.$; $\mathrm{D}_{60}$ (Particle size of the filter with a cumulative weight of $60 \%)=2 \mathrm{~mm})(50 \%)$;

(b) Transition layer (50-100 mm): coarse sand $\left(0.5-2 \mathrm{~mm} ; \mathrm{D}_{60}=1 \mathrm{~mm}\right)$;

(c) Saturated zone (200-300 mm) with or without carbon source: (i) fine gravel $(95 \%$; $6-10 \mathrm{~mm}$; $\mathrm{D}_{60}=8 \mathrm{~mm}$ ); and (ii) with and without wood chips (5\%).

Each mesocosm was planted with Hymenocallis speciosa. Hymenocallis speciosa was chosen because this species of plant can tolerate both flooding and dry weather conditions. There were 12 plants within a seedling stage in each tank. Irrigated with tap water, the plants were grown for 8 weeks in the mesocosms filled with filter media. Before the experiment began, the BCs were flushed four times for 2 weeks with artificial storm runoff to promote the development of natural biofilm.

For ensuring a stable inflow quality to BCs during the experiments, synthetic storm runoff was prepared by adding predetermined levels of chemicals into tap water, and was stored in plastic containers with the capacity of $150 \mathrm{~L}$ until use. The target chemical makeup of stormwater applied as synthetic runoff to bioretention system is presented in Table 1, largely in accordance with previous reported stormwater characteristics [45-48]. Suspended solids (SS) were not included in the synthetic stormwater because of the potential for adsorption of the positively charged ammonium and metal ions at an unknown rate onto these particles during storage, and the absence of research standards relating to particulate size and ion-exchange properties. For this reason, the study referred to a number of published studies in omitting SS from their versions of synthetic stormwater [20,49].

Table 1. The characteristics of the synthetic storm runoff in this study.

\begin{tabular}{ccc}
\hline & Influent Concentration $\left(\mathbf{m g ~ L}^{-\mathbf{1}}\right)$ & Pollutant Source \\
\hline $\mathrm{pH}$ & 7.0 & Hydrogen chloride $(\mathrm{HCl})$ or Sodium hydroxide $(\mathrm{NaOH})$ \\
Phosphorus & $2.0($ as $\mathrm{P})$ & Potassium phosphate $\left(\mathrm{KH}_{2} \mathrm{PO}_{4}\right)$ \\
Nitrate & $2.0($ as N) & Potassium nitrate $\left(\mathrm{KNO}_{3}\right)$ \\
Ammonium & $0.5($ as N) & Ammonium sulphate $\left(\mathrm{NH}_{4}\right)_{2} \mathrm{SO}_{4}$ \\
Copper & 0.5 & Copper chloride $\left(\mathrm{CuCl}_{2}\right)$ \\
Zinc & 1.0 & Zinc chloride $\left(\mathrm{ZnCl}_{2}\right)$ \\
\hline
\end{tabular}

The synthetic storm runoff was continuously pumped to the top of the cells using a peristaltic pump at three different flow rate 11.2, 5.6 and $2.8 \mathrm{~mL} \mathrm{~L}^{-1}$ to reach HRT 1, 2 and 3 day, respectively. Effluent was also collected from the bottom of the cell every two days. The experiment cells in each HRT were continuously run two months. The experiment was operated from April to October 2016.

Effluent samples were collected from the underdrain pipe of each BC every 1,2 and 3 day for different HRT in a 1-L amber glass bottle transported refrigerated to the laboratory and stored in a refrigerator at $4{ }^{\circ} \mathrm{C}$ until they were analyzed. The samples were immediately analyzed to investigate the concentration of the physicochemical parameters regarding temperature, dissolved oxygen (DO), $\mathrm{pH}$ value and conductivity measured using Multi-Parameter Digital Meter (HACH-HQ40d, Hach Company, Loveland, $\mathrm{CO}$, USA) directly. In addition, ammonia- $\mathrm{N}\left(\mathrm{NH}_{4}{ }^{+}-\mathrm{N}\right)$, nitrate $\left(\mathrm{NO}_{3}{ }^{-}-\mathrm{N}\right)$, and total phosphorus (TP), were analyzed using spectrophotometer (HACH-DR3800, Hach Company, Loveland, CO, USA) in accordance with the standard methods [50]. Heavy metals were analyzed using nitric acid digestion followed by mass spectrometric analysis using an Elan DRC-e ICP-MS (Perkin Elmer, Waltham, MA, USA). Instrument detection limits were $0.5 \mu \mathrm{g} \mathrm{L}{ }^{-1}$ for all the heavy metal tested. The monitoring results were tested for normal distribution. Investigating statistical differences 
between treatments were carried out by comparing the critical value through one-way analysis of variance. Comparisons were considered significantly different for $p<0.05$ [51].

\section{Results and Discussion}

\subsection{Physicochemical Parameters}

Table 2 shows the results of the physicochemical parameters in the effluent of BCs. Only dissolved oxygen (DO) showed significant differences among the mesocosms, with the effluent level of DO in module (c) (with a $200 \mathrm{~mm} \mathrm{SZ}$ and C) which was significantly lower $(p<0.05)$ than any of the other modules. Several studies have shown that DO (and redox potential) decrease in the SZ of BCs [52]. Similarly in the present study, applying an SZ combined with C decreased the DO concentration in the effluent to the level of 4.55-6.08 $\mathrm{mg} \mathrm{L}^{-1}$ at three HRTs in module (c). In comparison, the DO concentration in the module (a) without SZ and $\mathrm{C}$ was in the rage of 7.07-8.55 $\mathrm{mg} \mathrm{L}^{-1}$. Moreover, the effluent DO level in the module (b) $\left(7.02-8.24 \mathrm{mg} \mathrm{L}^{-1}\right)$ was slightly higher than those in the module (d) (7.21-8.28 $\left.\mathrm{mg} \mathrm{L}^{-1}\right)$, indicating the impact of additional exogenous carbon. This finding is in agreement with the results reported by Blecken et al. [52] indicating both SZ and addition of $C$ could decrease the DO concentration from around 8.5 to $6.0 \mathrm{mg} \mathrm{L}^{-1}$.

Table 2. The physicochemical parameters in the effluent of bioretention mesocosms.

\begin{tabular}{cccccc}
\hline & HRT (day) & Temperature $\left({ }^{\circ} \mathbf{C}\right)$ & $\mathbf{p H}$ & Conductivity $\left(\mathbf{S ~ m}^{-\mathbf{1}}\right)$ & $\mathbf{D O}_{(\mathbf{m g ~ L}}{ }^{\mathbf{1}}$ ) \\
\hline & $1(\mathrm{n}=20)$ & $24.04 \pm 2.45$ & $6.50 \pm 0.21$ & $377 \pm 67$ & $7.07 \pm 0.64$ \\
(a) & $2(\mathrm{n}=15)$ & $24.18 \pm 2.60$ & $7.40 \pm 0.45$ & $521 \pm 117$ & $7.86 \pm 0.48$ \\
& $3(\mathrm{n}=10)$ & $24.09 \pm 2.33$ & $6.55 \pm 0.51$ & $337 \pm 57$ & $8.55 \pm 0.39$ \\
\hline & $1(\mathrm{n}=20)$ & $23.94 \pm 2.70$ & $6.39 \pm 0.17$ & $395 \pm 55$ & $7.02 \pm 0.60$ \\
(b) & $2(\mathrm{n}=15)$ & $24.15 \pm 3.04$ & $7.11 \pm 0.45$ & $615 \pm 107$ & $7.29 \pm 0.70$ \\
& $3(\mathrm{n}=10)$ & $24.09 \pm 2.57$ & $6.26 \pm 0.24$ & $371 \pm 46$ & $8.24 \pm 0.62$ \\
\hline & $1(\mathrm{n}=20)$ & $23.89 \pm 2.67$ & $6.27 \pm 0.10$ & $585 \pm 92$ & $4.55 \pm 1.57$ \\
(c) & $2(\mathrm{n}=15)$ & $24.69 \pm 3.12$ & $6.88 \pm 0.46$ & $719 \pm 102$ & $5.81 \pm 0.73$ \\
& $3(\mathrm{n}=10)$ & $24.51 \pm 2.39$ & $6.10 \pm 0.21$ & $512 \pm 77$ & $6.08 \pm 0.58$ \\
\hline & $1(\mathrm{n}=20)$ & $23.99 \pm 2.48$ & $6.72 \pm 0.29$ & $525 \pm 75$ & $7.21 \pm 0.64$ \\
(d) & $2(\mathrm{n}=15)$ & $23.99 \pm 2.24$ & $7.41 \pm 0.55$ & $599 \pm 116$ & $7.80 \pm 0.50$ \\
& $3(\mathrm{n}=10)$ & $23.96 \pm 2.33$ & $6.31 \pm 0.22$ & $423 \pm 31$ & $8.28 \pm 0.44$ \\
\hline
\end{tabular}

Note: $\mathrm{n}$ is number.

\subsection{Nitrogen Removal}

The mean effluent concentrations of nitrogen (nitrate- $\mathrm{N}$ and ammonia- $\mathrm{N}$ ) and phosphorus (dissolved and total $\mathrm{P}$ ) for each $\mathrm{BC}$ are shown in Table 3. Poor $\mathrm{NO}_{3}{ }^{-}$removal in $\mathrm{BC}$ has been reported by many researchers $[24,53]$. High infiltration rates in $\mathrm{BCs}$ are likely to limit $\mathrm{NO}_{3}{ }^{-}$removal by denitrification [26]. There are limited times for its biogeochemical processes and transformations. The effects of the additional exogenous carbon to drive denitrification could be clearly seen in BCs with the removal of nitrate $\left(\mathrm{NO}_{3}{ }^{-}\right)$in module (c) with $\mathrm{C}$ showing significant $(p<0.05)$ enhancement $(85 \%, 87 \%$ and $94 \%)$ at all three HRTs, respectively, compared to the removal efficiency by module (d) without C (74\%, 76\% and $82 \%$ at three HRTs, respectively) (Figure $2 \mathrm{~A})$. The fact that the addition of carbon source as electro donor can facilitate denitrification and improve $\mathrm{NO}_{3}{ }^{-}$removal in bioretention system has also been reported by other studies [38,54]. The results also indicated that the removal of $\mathrm{NO}_{3}{ }^{-}$in module (c) with shallow SZ $(200 \mathrm{~mm})$ showed significant $(p<0.05)$ enhancement $(85 \%$, $87 \%$ and $94 \%$ at three HRTs, respectively) compared to those in the module (b) with deep SZ (300 mm) (71\%, $73 \%$ and $86 \%$ at three HRTs, respectively). This might be due to the low DO concentrations in module (c) which facilitated the denitrification process. In general, the SZ can be characterized as a partly anoxic zone. However, given the relatively high DO concentrations in the tested BCs, in addition to denitrification, there must have been other removal mechanisms for $\mathrm{NO}_{3}{ }^{-}$removal, such as plant 
uptake. Lucas and Greenway [55] reported that nitrogen uptake seemed to exceed the amount of nitrogen retained in the treatments, suggesting that plants obtained additional nitrogen from the media and denitrification was not a major pathway involved in nitrogen proceedings. Moreover, compared to other modules, the poor $\mathrm{NO}_{3}{ }^{-}$removal performance in module (a) might be attributed to leaching of nitrate in unplanted systems when nitrification occurred during dry inter-event periods [56]. In addition, SZ resulted in improving the stability with less leaching for removal performance, and the addition $C$ is also relevant with higher levels of nutrients and water for the plants [49]. This concept of controlling redox conditions and organic content could therefore prove beneficial in areas where nitrate pollution is a major concern. The question remains, however, exactly why the mesocosms with the shallower submerged zone $(200 \mathrm{~mm}$ as opposed to $300 \mathrm{~mm}$ ) showed such significantly enhanced treatment performance. The leaching of nutrient from the compost-rich media and the immature state of the plants with weeks growing time resulting in the reduced root mass across the filter media profile, might be the main influential factors contributing to enhanced performance from the shallower system.

Table 3. The mean effluent concentrations of nitrogen and phosphorus $\left(\mathrm{mg} \mathrm{L}^{-1}\right)$ for bioretention mesocosms.

\begin{tabular}{|c|c|c|c|c|c|}
\hline & HRT (day) & $\mathrm{NH}_{4}{ }^{+}-\mathrm{N}\left(\mathrm{mg} \mathrm{L}^{-1}\right)$ & $\mathrm{NO}_{3}{ }^{-}-\mathrm{N}\left(\mathrm{mg} \mathrm{L}^{-1}\right)$ & $\mathrm{PO}_{4}{ }^{3-}\left(\mathrm{mg} \mathrm{L}^{-1}\right)$ & $\mathrm{TP}\left(\mathrm{mg} \mathrm{L}^{-1}\right)$ \\
\hline \multirow{3}{*}{ (a) } & $1(\mathrm{n}=20)$ & $0.35 \pm 0.05$ & $0.63 \pm 0.13$ & $0.92 \pm 0.21$ & $1.60 \pm 0.31$ \\
\hline & $2(\mathrm{n}=15)$ & $0.35 \pm 0.07$ & $0.56 \pm 0.09$ & $0.52 \pm 0.12$ & $1.50 \pm 0.12$ \\
\hline & $3(\mathrm{n}=10)$ & $0.25 \pm 0.11$ & $0.46 \pm 0.13$ & $0.65 \pm 0.15$ & $1.48 \pm 0.19$ \\
\hline \multirow{3}{*}{ (b) } & $1(\mathrm{n}=20)$ & $0.23 \pm 0.05$ & $0.59 \pm 0.14$ & $1.02 \pm 0.29$ & $1.52 \pm 0.20$ \\
\hline & $2(\mathrm{n}=15)$ & $0.16 \pm 0.07$ & $0.54 \pm 0.08$ & $1.10 \pm 0.33$ & $1.63 \pm 0.30$ \\
\hline & $3(\mathrm{n}=10)$ & $0.15 \pm 0.09$ & $0.28 \pm 0.08$ & $0.78 \pm 0.31$ & $1.53 \pm 0.15$ \\
\hline \multirow{3}{*}{ (c) } & $1(n=20)$ & $0.11 \pm 0.07$ & $0.29 \pm 0.08$ & $0.30 \pm 0.08$ & $0.65 \pm 0.16$ \\
\hline & $2(\mathrm{n}=15)$ & $0.07 \pm 0.05$ & $0.26 \pm 0.06$ & $0.24 \pm 0.02$ & $0.58 \pm 0.22$ \\
\hline & $3(\mathrm{n}=10)$ & $0.04 \pm 0.02$ & $0.13 \pm 0.02$ & $0.20 \pm 0.04$ & $0.52 \pm 0.09$ \\
\hline \multirow{3}{*}{ (d) } & $1(n=20)$ & $0.22 \pm 0.06$ & $0.51 \pm 0.11$ & $0.42 \pm 0.13$ & $1.62 \pm 0.22$ \\
\hline & $2(\mathrm{n}=15)$ & $0.19 \pm 0.09$ & $0.48 \pm 0.10$ & $0.39 \pm 0.02$ & $1.11 \pm 0.18$ \\
\hline & $3(\mathrm{n}=10)$ & $0.11 \pm 0.05$ & $0.36 \pm 0.07$ & $0.34 \pm 0.12$ & $1.03 \pm 0.16$ \\
\hline
\end{tabular}

HRT has been reported to be crucial for nitrogen removal in BCs in many studies [57-60]. Figure 3 shows that the removal rate of nitrate was linearly related to HRT at the 1 to 3 day retention times to test, most likely reflecting first-order kinetics of denitrification in these reactors. The removal efficiencies of nitrate in each module increased with the increase in HRT. This finding is in good agreement with previous bioretention studies. Kim et al. [27] systematically evaluated a retrofitted bioretention system for nitrate removal via microbial denitrification, which incorporated a continuously SZ with an overdrain. The results from the nitrate loading and hydraulic loading studies in the second phase indicated that the mass of nitrate only, nitrate plus nitrite, and total nitrogen removed per day as a function of the volumetric nitrate loading. Lucas and Greenway [55] investigated P retention in bioretention mesocosms using media amended with different materials, and indicated that P retention by barren media eventually becomes exhausted under accelerated loading (24.5-29.3 m year) used to simulate long-term exposure, even when the media is amended with P-sorbing materials.

The removal of ammonia $\left(\mathrm{NH}_{4}{ }^{+}\right)$in module (c) with shallow SZ $(200 \mathrm{~mm})$ showed significant $(p<0.05)$ enhancement $(78 \%, 87 \%$ and $91 \%$ at three HRTs, respectively) compared to those in module (b) with deep SZ (300 mm) (54\%, 69\% and 71\% at three HRTs, respectively) (Figure 2B). Moreover, $\mathrm{NH}_{4}{ }^{+}$ removal at all three HRTs in module (c) also showed significant $(p<0.05)$ enhancement compared to those in module (d), indicating that the depth of the SZ is an important design parameter which cannot be overlooked. Additionally, modules (b), (c) and (d) showed significantly $(p<0.05)$ enhanced $\mathrm{NH}_{4}{ }^{+}$removal at all three HRTs compared to those in module (a) with no SZ or plants (Figure 3). Many researchers have reported that the removal of ammonia was mostly related to the adsorption on soil media during runoff dosing and nitrification during or between events [41]. In our study, the better ammonium removal in module (c) (compared to module (b)) may be attributed to the 
thicker upper layer (with a corresponding greater contact surface and retention time for ammonium adsorption) and relatively shallow SZ (with a more oxygenated condition to stimulate nitrification). Additionally, the significant $(p<0.05)$ enhanced $\mathrm{NH}_{4}{ }^{+}$removal in module (c) (compared to module $(\mathrm{d})$ ) can be directly attributed to the addition of $C$, although the reason why exogenous carbon stimulates ammonia removal remains unclear.
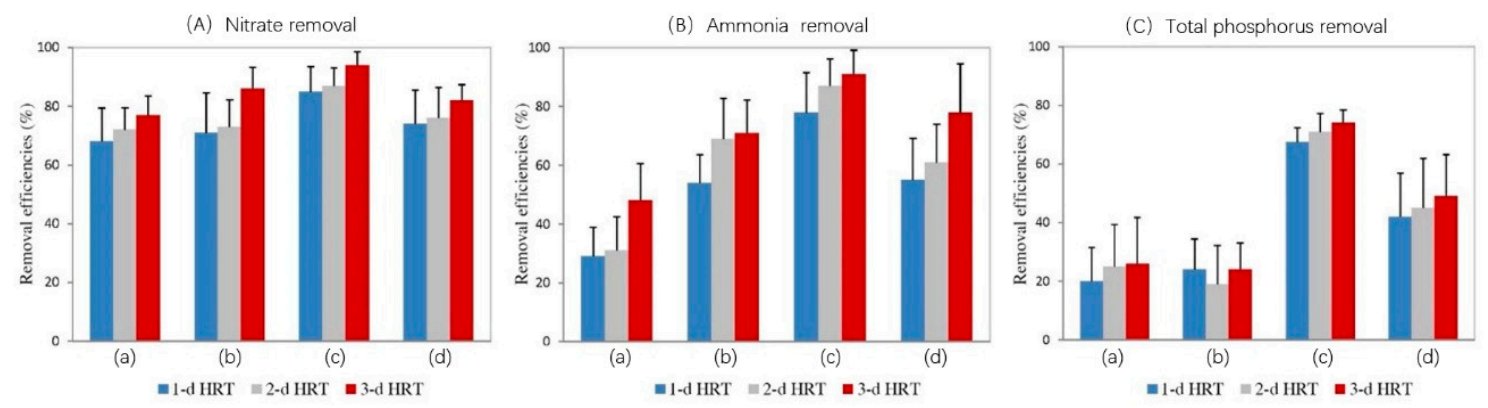

Figure 2. Nutrient removal efficiencies (\%) at different HRTs (day). Vertical error bars present standard deviation. (A) nitrate removal; (B) ammonia removal; and (C) total phosphorus removal.

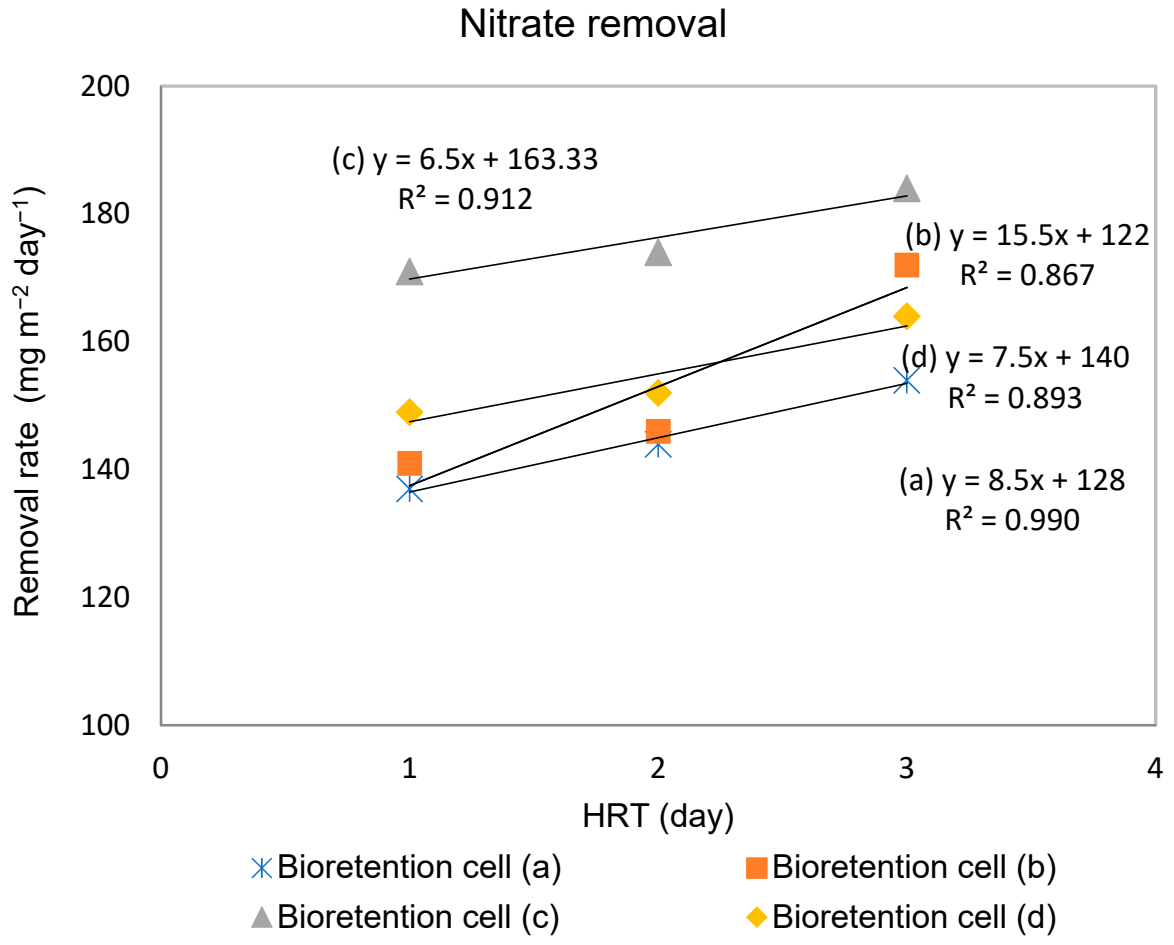

Figure 3. Correlation between nitrate removal rate $\left(\mathrm{mg} \mathrm{m}^{-2}\right.$ day $\left.^{-1}\right)$ and HRT (day).

\subsection{Phosphorous Removal}

Many studies have found that the soil compartment is the major long-term phosphorus (P) storage pool and adsorption is the most important retention mechanism [60-62]. Plants only contain a small amount of TP, thus TP uptake capacity of macrophytes is limited [56]. Due to the minor role plant uptake plays in TP removal, module (a) was used as a control in the present study to examine the effect of a submerged zone on P removal. The removal efficiency in the mesocosm with the SZ alone showed significant $(p<0.05)$ enhancement in TP removal: TP removal efficiency in module $(d)$ with SZ (42\%, 45\% and 49\% at the three HRTs, respectively) was significantly enhanced, compared to module (a) without SZ $(20 \%, 28 \%$ and $26 \%$ at three HRTs, respectively). This finding is consistent with a previous study conducted by Zhang et al. [54] who also reported that the removal for P significantly increased in the cell with SZ. Although the previous study by Lucas and Greenway [63] clearly showed 
that the presence of vegetation improved $\mathrm{P}$ removal, due to the immature plant development in the new cells given the short experimental period in the present study, we were unable to reconfirm the role of the plant in P removal. The poor TP removal performance in module (a) (sand filter alone) might best be attributed to a high level of leaching. Henderson et al. [51] reported that TP leaching was observed from a non-vegetated system when flushed with tap water under synthetic runoff applications, whereas leaching occurred in vegetated systems. In spite of this, in module (b) which has both plants and an SZ, TP removal efficiencies remained rather low (24\%, 19\% and 24\% at three HRTs, respectively) (Figure $2 \mathrm{C}$ ). These results point to the minimal role that vegetation plays in $\mathrm{P}$ removal in these BCs. As for the effects of SZ depth on TP removal, our results indicated that the removal of TP in module (c) with shallow SZ $(200 \mathrm{~mm})$ showed significant $(p<0.05)$ enhancement $(72 \%, 71 \%$ and $74 \%$ at three HRTs, respectively) compared to those in the module (b) with deep SZ (300 mm) (24\%, $19 \%$ and $24 \%$ at three HRTs, respectively). A previous study has demonstrated that the addition of carbon sources (e.g., methanol) has no effect on effluent P concentration in bioretention systems [41]. Surprisingly, in the present study, given the same SZ depth, module (c) with C showed significant $(p<0.05)$ enhancement $(72 \%, 71 \%$ and $74 \%$ at three HRTs, respectively) compared to the module (d) without C (42\%, $45 \%$ and $49 \%$ at three HRTs, respectively).

\subsection{Metal Removal}

Copper $(\mathrm{Cu})$, zinc $(\mathrm{Zn})$ and lead $(\mathrm{Pb})$ were selected for testing in the present study on heavy metal removal because there is robust literature on these metals in previous BCs research including both laboratory and field studies $[19,64,65]$. At low concentrations, through their bioavailability and bioaccumulation in the aquatic environment, these pollutants may result in reduction of biodiversity and ultimately the contamination of human water and food supplies [66,67]. Some of the heavy metals can have acute or chronic impacts on aquatic habitats, drinking water resources and recreational uses [68]. In terms of potential toxic effects, the partitioning between the total and dissolved heavy metals is essential because the dissolved fractions are the most important ecotoxicants in stormwater and are directly biologically available [69]. In particular, $\mathrm{Zn}$ and Cu have been shown to exhibit the highest intrinsic ecotoxicity in biomonitoring experiments using representative fish, algae, and macroinvertebrates, based on a number of runoff stages during rainfall events [70]. Therefore, $\mathrm{Zn}$ deserves a high profile in research relating to urban stormwater contamination, whereas $\mathrm{Cu}$ might be a preferred indicator for atmospheric-mediated stormwater pollution, particularly where smelting of associated heavy metals occurs [20].

With influent levels of $\mathrm{Cu}, \mathrm{Zn}$, and $\mathrm{Pb}$ at 500, 1000 and $10 \mu \mathrm{g} \mathrm{L}{ }^{-1}$, removal efficiencies greater than $93 \%$ were observed in our BCs for each of the metals tested (Figure 4). Table 4 presents the mean effluent concentrations of heavy metals and removal efficiencies. This find is in good agreement with those of several other researches regarding that the effective performance of heavy metal removal from storm runoff (e.g., $\mathrm{Cu}, \mathrm{Zn}$, and $\mathrm{Pb}$ removal in excess of 90\%). The filter media is the most important component affecting heavy metal removal [71]. Sun and Davis [47] studied the capture of heavy metals in a bioretention system using three plant species with high biomass productivity, and reported that 88-97\% of all inflowing metals were captured within the soil media, while the accumulation in plant tissue only accounted for $0.5-3.3 \%$ of the metals. Heavy metal removal has been shown to be high for a variety of different soil media, even in unvegetated soil filters, suggesting that the soil, rather than vegetation, plays the dominant role in metal removal $[47,70]$. Since plants in biofilters have been shown to have a minor role [72], in our present study, module (a) without plants, served as an unplanted control to compare the removal efficiencies with other planted modules. In general, physical filtration also plays a role in contaminant removal, since heavy metals and some portion of $\mathrm{P}$ and $\mathrm{N}$ may attach to the sediment. For instance, $\mathrm{Pb}$ salts on road are mainly particle-bound. Thus, metal removal by bioretention may be an important strategy in avoiding accumulation of these substances in receiving water sediment. However, as the addition of suspended particulate matter to the simulated stormwater was not considered in this study the role of physical filtration seemed less important in the present 
study. Nevertheless, future field research on the metal removal by biofiltration and sedimentation is however needed.
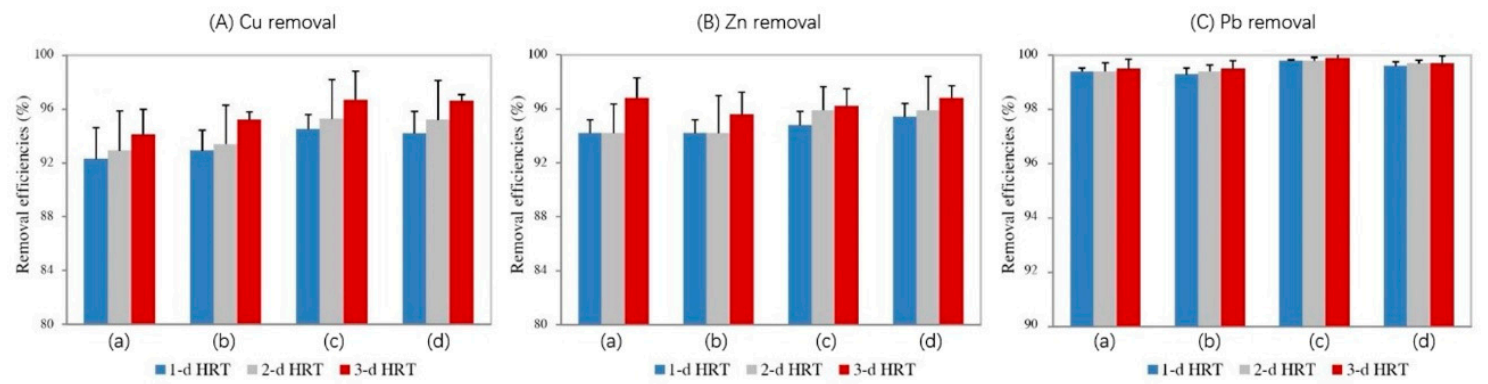

Figure 4. Removal efficiencies (\%) for heavy metals at different HRTs (day). Vertical error bars present standard deviation. (A) Cu removal; (B) Zn removal; and (C) Pb removal.

Table 4. The mean effluent concentrations $\left(\mathrm{mg} \mathrm{L}^{-1}\right)$, removal efficiencies (\%) and standard deviations $(\mathrm{SD})( \pm)$ of heavy metals for bioretention mesocosms.

\begin{tabular}{ccccc}
\hline & HRT (day) & $\mathbf{C u}\left(\mu \mathbf{g ~ L}^{-\mathbf{1}}\right)$ & $\mathbf{Z n}\left(\mu \mathbf{g ~ L}^{-\mathbf{1}}\right)$ & $\mathbf{P b}\left(\boldsymbol{\mu g} \mathbf{L}^{-\mathbf{1}}\right)$ \\
\hline & $1(\mathrm{n}=20)$ & $38.44 \pm 8.45(92.3 \%)$ & $58.28 \pm 13.07(94.8 \%)$ & $0.64 \pm 0.09(93.6 \%)$ \\
$(\mathrm{a})$ & $2(\mathrm{n}=15)$ & $35.54 \pm 9.87(92.9 \%)$ & $58.49 \pm 9.89(94.2 \%)$ & $0.58 \pm 0.10(94.2 \%)$ \\
& $3(\mathrm{n}=10)$ & $29.57 \pm 5.31(94.1 \%)$ & $31.80 \pm 5.78(96.8 \%)$ & $0.52 \pm 0.21(94.8 \%)$ \\
\hline & $1(\mathrm{n}=20)$ & $35.52 \pm 4.62(92.9 \%)$ & $58.46 \pm 5.95(94.0 \%)$ & $0.71 \pm 0.13(92.9 \%)$ \\
$(b)$ & $2(\mathrm{n}=15)$ & $32.99 \pm 8.44(93.4 \%)$ & $55.57 \pm 7.41(94.4 \%)$ & $0.65 \pm 0.14(93.5 \%)$ \\
& $3(\mathrm{n}=10)$ & $24.05 \pm 3.30(95.2 \%)$ & $43.58 \pm 7.67(95.6 \%)$ & $0.48 \pm 0.08(95.2 \%)$ \\
\hline & $1(\mathrm{n}=20)$ & $27.28 \pm 4.41(94.5 \%)$ & $51.93 \pm 11.64(94.8 \%)$ & $0.20 \pm 0.02(98.0 \%)$ \\
(c) & $2(\mathrm{n}=15)$ & $23.59 \pm 9.05(95.5 \%)$ & $41.30 \pm 8.04(95.9 \%)$ & $0.17 \pm 0.04(98.3 \%)$ \\
& $3(\mathrm{n}=10)$ & $16.43 \pm 4.31(96.8 \%)$ & $38.12 \pm 9.90(96.2 \%)$ & $0.15 \pm 0.14(98.5 \%)$ \\
\hline & $1(\mathrm{n}=20)$ & $29.19 \pm 7.09(94.2 \%)$ & $45.73 \pm 8.39(95.4 \%)$ & $0.38 \pm 0.15(96.2 \%)$ \\
(d) & $2(\mathrm{n}=15)$ & $13.90 \pm 10.37(97.2 \%)$ & $41.01 \pm 5.91(95.9 \%)$ & $0.32 \pm 0.05(96.8 \%)$ \\
& $3(\mathrm{n}=10)$ & $16.79 \pm 4.57(96.6 \%)$ & $32.19 \pm 5.49(96.7 \%)$ & $0.30 \pm 0.47(97.0 \%)$ \\
\hline
\end{tabular}

The investigation of the effects of an SZ on metal removal performance showed that $\mathrm{Cu}$ removal ranged from 94 to $97 \%$ at all three HRTs in module (d) with an SZ, and was significantly $(p<0.05)$ enhanced compared to the removal efficiencies (92-94\%) in module (a) without a SZ. For Pb, significant enhancement in module (c) compared to module (a) was also observed. In contrast, no significant $(p>0.05)$ enhancement was observed for Zn removal in module (c) with SZ. Higher heavy metal concentrations are observed after drought periods, and drying of soil is also associated with inactivity of biofilms and death of microorganisms and plant cells, which may result in flushing of a metal organic complex [73]. However, SZ can provide a buffer to both soil and the plants against prolonged drying. Moreover, the creation of semi-anoxic zone through SZ is favorable for metal sorption to sediments [29], since heavy metals could be mobilized into the environment due to oxidation of sediments [74].

Additionally, the enhancement of heavy metal removal by the presence of SZ combined with $\mathrm{C}$ in BCs has been reported by numerous studies [28]. The addition of C might improve complexation between copper and organic matter, due to solid organic matter absorbing $\mathrm{Cu}$ as the main component [75], while the other two metals possess lower affinity to organic matter [57]. In order to investigate the role of carbon source in metal removal, metal removal by module (c) was compared with that of module $(\mathrm{d})$. For $\mathrm{Cu}$ and $\mathrm{Pb}$, no improvement was observed in module (c), compared with module (d), although a slight enhancement of $\mathrm{Zn}$ removal was observed in module (c) as compared to module (d). Our results are similar to other recent research by Blecken et al. [52] which demonstrated that the introduction of an SZ helps to enhance removal of $\mathrm{Cu}$, but that no significantly better performance was observed for $\mathrm{Pb}$ or $\mathrm{Zn}$. Even in the case of $\mathrm{Cu}$, Blecken et al. [52] found that 
removal is only about 7\% higher in columns with both an SZ and C as opposed to those without. These results clearly point to only a marginal enhancement of metal removal by an SZ (with or without added carbon) in marked contrast to the performance benefit for nitrogen removal conferred by an SZ with exogenous carbon added.

\section{Conclusions}

This study demonstrated a new module bioretention system with great flexibility and simple maintenance in urban area of Sponge City, China. This module system can not only prevent drainage clogging, but also speed up the establishment process and reduce the chances of soil erosion. A submerged (anoxic) zone combined with carbon source $(C)$ significantly $(p<0.05)$ enhanced the removal of nutrients (i.e., $\mathrm{NO}_{3}{ }^{-}, \mathrm{NH}_{4}{ }^{+}$and TP) in the bioretention systems. The bioretention cells with a shallow depth $(200 \mathrm{~mm})$ of SZ showed better nutrients removal compared to that with deep SZ (300 mm). With influent levels of $\mathrm{Cu}, \mathrm{Zn}$, and $\mathrm{Pb}$ at 500,1000 and $10 \mu \mathrm{g} \mathrm{L}{ }^{-1}$, removal efficiencies greater than $93 \%$ were observed in our BCs for each of the metals tested. The addition of SZ significantly enhanced the removal efficiencies of $\mathrm{Cu}$ and $\mathrm{Pb}$. For $\mathrm{Cu}$ and $\mathrm{Pb}$, no improvement was observed in the presence of carbon source, and a slight enhancement of $\mathrm{Zn}$ removal was observed with carbon addition. The removal rate of nitrate was linearly related to HRT at the 1 to 3 day of retention time tested. Although the enhancement of metal removal by an SZ (with or without C) was not distinct, removal efficiencies greater than 93\% were observed in all of the mesocosms for each of the metals tested. Future studies should be carried out to examine the effectiveness of these BCs containing an SZ and additional $\mathrm{C}$ in field-scale trials for storm runoff treatment.

Author Contributions: conceptualization, M.W. and D.Z.; methodology, D.Z.; software, Y.L.; validation, Q.H., Y.Y. and J.Q.; formal analysis, W.F.; investigation, M.W.; resources, Y.C.; data curation, Q.H.; writing-original draft preparation, M.W.; writing-review and editing, D.Q.; visualization, J.Q.; supervision, J.D.; project administration, Y.C.; funding acquisition, Y.C.

Funding: The project was funded by the National Natural Science Foundation of China (Grant No. 51808137, and No. 51838003).

Conflicts of Interest: The authors declare no conflict of interest.

\section{References}

1. Miller, J.D.; Kim, H.; Kjeldsen, T.R.; Packman, J.; Grebby, S.; Dearden, R. Assessing the impact of urbanization on storm runoff in a peri-urban catchment using historical change in impervious cover. J. Hydrol. 2014, 515, 59-70. [CrossRef]

2. Hamel, P.; Daly, E.; Fletcher, T.D. Source-control stormwater management for mitigating the impacts of urbanisation on baseflow: A review. J. Hydrol. 2013, 485, 201-211. [CrossRef]

3. Shafique, M. Rainfall runoff mitigation by retrofitted permeable pavement in an urban area. Sustainability 2018, 10, 1231. [CrossRef]

4. Bonneau, J.; Burns, M.J.; Fletcher, T.D.; Witt, R.; Drysdale, R.N.; Costelloe, J.F. The impact of urbanization on subsurface flow paths-A paired-catchment isotopic study. J. Hydrol. 2018, 561, 413-426. [CrossRef]

5. Dietz, M.E. Low impact development practices: A review of current research and recommendations for future directions. Water Air Soil Poll. 2015, 22, 543-563. [CrossRef]

6. Yang, Y.; Chui, T.F.M. Integrated hydro-environmental impact assessment and alternative selection of low impact development practices in small urban catchments. J. Environ. Manag. 2018, 223, 324-337. [CrossRef] [PubMed]

7. Trowsdale, S.A.; Simcock, R. Urban stormwater treatment using bioretention. J. Hydrol. 2011, 397, 167-174. [CrossRef]

8. Dagenais, D.; Thomas, I.; Paquette, S. Siting green stormwater infrastructure in a neighbourhood to maximise secondary benefits: Lessons learned from a pilot project. Landsc. Res. 2017, 42, 1-16. [CrossRef]

9. Wang, M.; Zhang, D.; Adhityan, A.; Ng, W.J.; Dong, J.; Tan, S.K. Assessing cost-effectiveness of bioretention on stormwater in response to climate change and urbanization for future scenarios. J. Hydrol. 2016, 543, 423-432. [CrossRef] 
10. Winston, R.J.; Dorsey, J.D.; Hunt, W.F. Quantifying volume reduction and peak flow mitigation for three bioretention cells in clay soils in northeast Ohio. Sci. Total Environ. 2016, 553, 83-95. [CrossRef] [PubMed]

11. Baek, S.S.; Choi, D.H.; Jung, J.W.; Lee, H.J.; Lee, H.; Yoon, K.S.; Cho, K.H. Optimizing low impact development (LID) for stormwater runoff treatment in urban area, Korea: Experimental and modeling approach. Water Res. 2015, 86, 122-131. [CrossRef] [PubMed]

12. Garcíaserrana, M.; Gulliver, J.S.; Nieber, J.L. Infiltration capacity of roadside filter strips with non-uniform overland flow. J. Hydrol. 2017, 545, 451-462. [CrossRef]

13. Zhou, Z.; Xu, P.; Cao, X.; Zhou, Y.; Song, C. Efficiency promotion and its mechanisms of simultaneous nitrogen and phosphorus removal in stormwater biofilters. Bioresour. Technol. 2016, 218, 842-849. [CrossRef] [PubMed]

14. Wang, M.; Zhang, D.; Dong, J.; Tan, S.K. Application of constructed wetlands for treating agricultural runoff and agro-industrial wastewater: A review. Hydrobiologia 2018, 805, 1-31. [CrossRef]

15. Muerdter, C.P.; Wong, C.K.; LeFevre, G.H. Emerging investigator series: The role of vegetation in bioretention for stormwater treatment in the built environment: Pollutant removal, hydrologic function, and ancillary benefits. Environ. Sci. Water Res. Technol. 2018, 4, 592-612. [CrossRef]

16. Kim, M.H.; Chan, Y.S.; Li, M.H.; Chu, K.H. Bioretention for stormwater quality improvement in texas: Removal effectiveness of escherichia coli. Sep. Purif. Technol. 2012, 84, 120-124. [CrossRef]

17. Shrestha, P.; Hurley, S.E.; Wemple, B.C. Effects of different soil media, vegetation, and hydrologic treatments on nutrient and sediment removal in roadside bioretention systems. Ecol. Eng. 2018, 112, 116-131. [CrossRef]

18. Wang, M.; Zhang, D.Q.; Su, J.; Dong, J.W.; Tan, S.K. Assessing hydrological effects and performance of low impact development practices based on future scenarios modeling. J. Clean. Prod. 2018, 179, 12-23. [CrossRef]

19. Liu, Z.; Li, J.; Li, P.; Li, Y.; Li, W. Study of Bioretention System on Heavy-Metal Removal Effect. Pol. J. Environ. Stud. 2018, 27, 163-173. [CrossRef]

20. Macnamara, J.; Derry, C. Pollution removal performance of laboratory simulations of Sydney's street stormwater biofilters. Water 2017, 9, 907. [CrossRef]

21. Kandel, S.; Vogel, J.; Penn, C.; Brown, G. Phosphorus Retention by Fly Ash Amended Filter Media in Aged Bioretention Cells. Water 2017, 9, 746. [CrossRef]

22. Hermawan, A.A.; Chang, J.W.; Pasbakhsh, P.; Hart, F.; Talei, A. Halloysite nanotubes as a fine grained material for heavy metal ions removal in tropical biofiltration systems. Appl. Clay Sci. 2018, 160, 106-115. [CrossRef]

23. Tedoldi, D.; Chebbo, G.; Pierlot, D.; Branchu, P.; Kovacs, Y.; Gromaire, M.C. Spatial distribution of heavy metals in the surface soil of source-control stormwater infiltration devices-Inter-site comparison. Sci. Total Environ. 2017, 579, 881-892. [CrossRef] [PubMed]

24. Hunt, W.F.; Smith, J.T.; Jadlocki, S.J.; Hathaway, J.M.; Eubanks, P.R. Pollutant removal and peak flow mitigation by a bioretention cell in urban Charlotte, N.C. J. Environ. Eng. 2008, 134, 403-408. [CrossRef]

25. Hsieh, D.H.; Davis, A.P. Multiple-event study of bioretention for treatment of urban stormwater runoff. Water Sci. Technol. 2005, 51, 177-181. [CrossRef] [PubMed]

26. Stander, E.K.; Borst, M. Hydraulic test of a bioretention media carbon amendment. J. Hydraul. Eng. 2010, 15, 531-536. [CrossRef]

27. Kim, H.; Seagren, E.A.; Davis, A.P. Engineered bioretention for removal of nitrate from stormwater runoff. Water Environ. Res. 2003, 75, 355-367. [CrossRef] [PubMed]

28. Zinger, Y.; Blecken, G.T.; Fletcher, T.D.; Viklander, M.; Deletić, A. Optimising nitrogen removal in existing stormwater biofilters: Benefits and tradeoffs of a retrofitted saturated zone. Ecol. Eng. 2013, 51, 5-82. [CrossRef]

29. Zinger, Y.; Fletcher, T.D.; Deletic, A.; Blecken, G.T.; Viklander, M. Optimisation of the nitrogen retention capacity of stormwater biofiltration systems. Surg. Endosc. Other Int. Tech. 2007, 17, 891-895.

30. Zinger, Y.; Deletic, A.; Fletcher, T. The effect of various intermittent dry-wet cycles on nitrogen removal capacity in biofilters systems. In Rainwater and Urban Design 2007; Engineers Australia: Barton, Australia, 2007; pp. 1195-1202.

31. Passeport, E.; Hunt, W.F.; Line, D.E.; Smith, R.A.; Brown, R.A. Field study of the ability of two grassed bioretention cells to reduce storm-water runoff pollution. J. Irrig. Drain Eng. 2009, 135, 505-510. [CrossRef] 
32. Dietz, M.E.; Clausen, J.C. Saturation to improve pollutant retention in a rain garden. Environ. Sci. Technol. 2006, 40, 1335-1340. [CrossRef] [PubMed]

33. Davis, A.P. Field performance of bioretention: Water quality. Environ. Eng. Sci. 2007, 24, $1048-1064$. [CrossRef]

34. Hatt, B.E.; Deletic, A.; Fletcher, T. D Stormwater reuse: Designing biofiltration system for reliable treatment. Water Sci. Technol. 2007, 55, 201-209. [CrossRef] [PubMed]

35. Davis, A.P.; Shokouhian, M.; Sharma, H.; Minami, C. Water quality improvement through bioretention media: Nitrogen and phosphorus removal. Water Environ. Res. 2006, 78, 284-293. [CrossRef] [PubMed]

36. Chen, X.; Peltier, E.; Sturm, B.S.; Young, C.B. Nitrogen removal and nitrifying and denitrifying bacteria quantification in a stormwater bioretention system. Water Res. 2013, 47, 1691-1700. [CrossRef] [PubMed]

37. Kratky, H.; Li, Z.; Chen, Y.; Wang, C.; Li, X.; Yu, T. A critical literature review of bioretention research for stormwater management in cold climate and future research recommendations. Front. Environ. Sci. Eng. 2017, 11, 23-37. [CrossRef]

38. Tahvonen, O. Adapting bioretention construction details to local practices in Finland. Sustainability 2018, 10, 276. [CrossRef]

39. Chan, F.K.S.; Griffiths, J.A.; Higgitt, D.; Xu, S.; Zhu, F.; Tang, Y.T.; Xu, Y.; Thorne, C.R. "Sponge City" in China-A breakthrough of planning and flood risk management in the urban context. Land Use Policy 2018, 76, 772-778. [CrossRef]

40. Afrooz, A.R.M.N.; Boehm, A.B. Effects of submerged zone, media aging, and antecedent dry period on the performance of biochar-amended biofilters in removing fecal indicators and nutrients from natural stormwater. Ecol. Eng. 2017, 102, 320-330. [CrossRef]

41. Huett, D.O.; Morris, S.G.; Smith, G.; Hunt, N. Nitrogen and phosphorus removal from plant nursery runoff in vegetated and unvegetated subsurface flow wetlands. Water Res. 2005, 39, 3259-3272. [CrossRef] [PubMed]

42. Pitt, R.; Clark, S.; Steets, B. Laboratory Evaluations to Support the Design of Bioretention Systems in the Southwestern US. In World Environmental and Water Resources Congress 2010: Challenges of Change; ASCE: Reston, VA, USA, 2010; pp. 2977-2993.

43. DeBusk, K.; Hunt, W.; Line, D. Bioretention outflow: Does it mimic nonurban watershed shallow interflow? J. Hydrol. Eng. 2011, 16, 274-279. [CrossRef]

44. FAWB (Facility for Advancing Water Biofiltration). Adoption Guidelines for Stormwater Biofiltration Systems: Facility for Advancing Water Biofiltration; Monash University: Melbourne, Australia, 2009.

45. Davis, A.P.; Hunt, W.F.; Traver, R.G.; Clar, M. Bioretention technology: Overview of current practice and future needs. J. Environ. Eng. 2009, 135, 109-117. [CrossRef]

46. Hatt, B.E.; Fletcher, T.D.; Deletic, A. Hydrologic and pollutant removal performance of stormwater biofiltration systems at the field scale. J. Hydrol. 2009, 365, 310-321. [CrossRef]

47. Sun, X.L.; Davis, A.P. Heavy metal fates in laboratory bioretention systems. Chemosphere 2007, 66, 1601-1609. [CrossRef] [PubMed]

48. Hsieh, C.; Davis, A.P. Evaluation and optimization of bioretention media for treatment of urban storm water runoff. J. Environ. Eng. 2005, 131, 1521-1531. [CrossRef]

49. Henderson, C.; Greenway, M.; Phillips, I. Removal of dissolved nitrogen, phosphorus and carbon from storm water by biofiltration mesocosms. Water Sci. Technol. 2007, 55, 183-191. [CrossRef] [PubMed]

50. American Public Health Association. Standard Methods for the Examination of Water and Wastewater, 17th ed.; American Public Health Association: Washington, DC, USA, 1989.

51. Zhang, D.Q.; Tan, S.K.; Gersberg, R.M.; Zhu, J.; Sadreddini, S.; Li, Y. Nutrient removal in tropical subsurface flow constructed wetlands under batch and continuous flow conditions. J. Environ. Manag. 2012, 96, 1-6. [CrossRef] [PubMed]

52. Blecken, G.T.; Zinger, Y.; Deletić, A.; Fletcher, T.D.; Viklander, M. Impact of a submerged zone and a carbon source on heavy metal removal in stormwater biofilters. Ecol. Eng. 2009, 35, 769-778. [CrossRef]

53. Mei, Y.; Gao, L.; Zhou, H.; Wei, K.H.; Cui, N.Q.; Chang, C.C. Ranking media for multi-pollutant removal efficiency in bioretention. Water Sci. Technol. 2018, 77, 2023-2035. [CrossRef] [PubMed]

54. Zhang, Z.; Rengel, Z.; Liaghati, T.; Antoniette, T.; Meney, K. Influence of plant species and submerged zone with carbon addition on nutrient removal in stormwater biofilter. Ecol. Eng. 2011, 37, 1833-1841. [CrossRef]

55. Lucas, W.C.; Greenway, M. Hydraulic response and nitrogen retention in bioretention mesocosms with regulated outlets: Part II-Nitrogen retention. Water Environ. Res. 2011, 83, 703-713. [CrossRef] [PubMed] 
56. Brix, H. Function of macrophytes in constructed wetlands. Water Sci. Technol. 1994, 29, 71-78. [CrossRef]

57. Masi, M. A swmm-5 model of a denitrifying bioretention system to estimate nitrogen removal from stormwater runoff. Diss. Theses Gradworks 2011, 69, 133-148.

58. Cho, K.W.; Song, K.G.; Cho, J.W.; Kim, T.G.; Ahn, K.H. Removal of nitrogen by a layered soil infiltration system during intermittent storm events. Chemosphere 2009, 76, 690-696. [CrossRef] [PubMed]

59. Faulkner, S.P.; Richardson, G.J. Physical and chemical characteristics of freshwater wetland soils. In Constructed Wetlands for Wastewater Treatment. Municipal, Industrial and Agricultural; Hammer, D.A., Ed.; Lewis Publishers: Chelsea, MI, USA, 1989; pp. 41-72.

60. RoyPoirier, A.; Champagne, P.; Filion, Y. Bioretention processes for phosphorus pollution control. Dossiers Environ. 2010, 18, 159-173. [CrossRef]

61. Jay, J.G.; Brown, S.L.; Kurtz, K.; Grothkopp, F. Predictors of phosphorus leaching from bioretention soil media. J. Environ. Qual. 2017, 46, 1098-1105. [CrossRef] [PubMed]

62. Anderson, C.R.; Condron, L.M.; Clough, T.J.; Fiers, M.; Stewart, A.; Hill, R.A.; Sherlock, R.R. Biochar induced soil microbial community change: Implications for biogeochemical cycling of carbon, nitrogen and phosphorus. Pedobiologia 2011, 54, 309-320. [CrossRef]

63. Lucas, W.C.; Greenway, M. Nutrient retention in vegetated and nonvegetated bioretention mesocosms. J. Irrig. Drain. Eng. 2008, 134, 613-623. [CrossRef]

64. Gülbaz, S.; Kazezy1lmaz-Alhan, C.M.; Copty, N.K. Evaluation of heavy metal removal capacity of bioretention systems. Water Air Soil Poll. 2015, 226, 376. [CrossRef]

65. Lim, H.S.; Lim, W.; Hu, J.Y.; Ziegler, A.; Ong, S.L. Comparison of filter media materials for heavy metal removal from urban stormwater runoff using biofiltration systems. J. Environ. Manag. 2015, 147, $24-33$. [CrossRef] [PubMed]

66. Bennasir, H.; Sridhar, S. Health hazards due to heavy metal poisoning and other factors in sea foods. Int. J. Pharm. Sci. Rev. Res. 2013, 18, 33-37.

67. Hrubá, F.; Strömberg, U.; Černá, M.; Chen, C.; Harari, F.; Harari, R.; Horvat, M.; Koppová, K.; Kos, A.; Krsková, A.; et al. Blood cadmium, mercury, and lead in children: An international comparison of cities in six European countries, and China, Ecuador, and Morocco. Environ. Int. 2012, 41, 29-34. [CrossRef] [PubMed]

68. Yousef, Y.A.; Wanielista, M.P.; Hvitved-Jacobsen, T.; Harper, H.H. Fate of heavy metals in stormwater runoff from highway bridges. Sci. Total Environ. 1984, 33, 233-244. [CrossRef]

69. Crabtree, B.; Dempsey, P.; Johnson, I.; Whitehead, M. The development of a risk-based approach to managing the ecological impact of pollutants in highway runoff. Water Sci. Technol. 2008, 57, 1595-1600. [CrossRef] [PubMed]

70. Kayhanian, M.; Stransky, C.; Bay, S.; Lau, S.L.; Stenstrom, M.K. Toxicity of urban highway runoff with respect to storm duration. Sci. Total Environ. 2008, 389, 386-406. [CrossRef] [PubMed]

71. Li, H.; Davis, A.P. Heavy metal capture and accumulation in bioretention media. Environ. Sci. Technol. 2008, 42, 5247-5253. [CrossRef] [PubMed]

72. Fritioff, Å.; Greger, M. Aquatic and terrestrial plant species with potential to remove heavy metals from stormwater. Int. J. Phytoremediat. 2003, 5, 211-224. [CrossRef] [PubMed]

73. Yin, Y.; Impellitteri, C.A.; You, S.-J.; Allen, H.E. The importance of soil organic matter distribution and extract soil: Solution ratio on the desorption of heavy metals form soils. Sci. Total Environ. 2002, 287, 107-119. [CrossRef]

74. Förstner, U.; Ahlf, W.; Calmano, W. Studies on the transfer of heavy metals between sedimentary phases with a multi-chamber device: Combined effects of salinity and redox variation. Mar. Chen. 1989, 28, 145-158. [CrossRef]

75. Temminghoff, E.J.; Van der Zee, S.E.; de Haan, F.A. Copper Mobility in a copper-contaminated sandy soil as affected by $\mathrm{pH}$ and solid and dissolved organic matter. Environ. Sci. Technol. 1997, 31, 1109-1115. [CrossRef]

(C) 2018 by the authors. Licensee MDPI, Basel, Switzerland. This article is an open access article distributed under the terms and conditions of the Creative Commons Attribution (CC BY) license (http:/ / creativecommons.org/licenses/by/4.0/). 